\title{
Estimate of the optimal level of concentrates for dairy cows on tropical pastures by using the concept of marginal analysis
}

\section{André Soares de Oliveira ${ }^{1^{*}}$, José Maurício de Souza Campos ${ }^{2}$, Rogério de Paula Lana ${ }^{2}$, Edenio Detmann², Sebastião de Campos Valadares Filho ${ }^{2}$}

\author{
1 Pós-Doutorando em Nutrição e Produção de Ruminantes, Departamento de Zootecnia, Universidade Federal de Viçosa, Viçosa-MG \\ CEP: 36571-000, Bolsista do CNPq. \\ ${ }^{2}$ Departamento de Zootecnia, Universidade Federal de Viçosa.
}

\begin{abstract}
It was adopted in this work a methodology to estimate the optimal level of concentrate food for dairy cows on tropical pastures based on the theory of marginal analysis. An empiric model was developed and validated for application of the methodology using a database composed of 62 means of treatments from 32 studies in which milk production was evaluated regarded to the levels of concentrate feeding. Milk production (MP) showed quadratic behavior in response to concentrate intake $(\mathrm{CI})$ : MP $(\mathrm{kg} / \mathrm{cow} /$ day $)=10.554+1.5855 \mathrm{CI}-0.0552 \mathrm{CI}^{2}$. Evaluation of the MP values observed over the predicted ones pointed the non-rejection of the null hypothesis, indicating that the model can be applied on the prediction of milk production, and consequently, on the optimal level of supplementation. However, evaluation of the partition of mean square error of prediction indicated the need for adjustments. The marginal production response (MPR) presented decreasing linear effect at CI level: MPR $(\mathrm{kg}$ milk $/ \mathrm{kg}$ concentrate added $)=1.5855-0.1104 \mathrm{CI}$. The intake of concentrate that maximizes profit per animal (CIoptimum) is estimated by the following equation: CIoptimum (kg/cow/day, as fed basis $)=(1.5855-(\mathrm{Px} / \mathrm{Py})) / 0.1104$; in which Px and Py are, respectively, the prices of concentrate feeds $(\$ / \mathrm{kg}$, as fed basis) and of the milk at farmgate $(\$ / \mathrm{kg})$. It is suggested the realization of new studies to include in the model, indicators of reproductive performance and other factors that affect the productive response to supplementation with concentrate feeds. Recommendations on levels of concentrate feeding for bovines should be based on presuppotions of marginal response theory, in order to avoid irrational use of nutrients.
\end{abstract}

Key Words: marginal production response, milk production, modeling, optimization

\section{Estimativa do nível ótimo de concentrado para vacas leiteiras em pastos tropicais utilizando-se o conceito de análise marginal}

\begin{abstract}
RESUMO - Adotou-se uma metodologia para estimar o nível ótimo de alimentos concentrados para vacas leiteiras em pastos tropicais com base na teoria da análise marginal. Um modelo empírico foi desenvolvido e validado para aplicação da metodologia, utilizando-se um banco de dados formado por 62 médias de tratamentos oriundos de 31 estudos em que a produção de leite foi avaliada em relação aos níveis de alimentação concentrada. A produção de leite (PL) apresentou comportamento quadrático em resposta ao consumo de concentrado (CC): PL (kg/vaca/dia) = 10,554 + 1,5855CC 0,0552CC ${ }^{2}$. A avaliação dos valores de produção de leite observados sobre os preditos de PL apontou a não-rejeição da hipótese de nulidade, indicando que o modelo pode ser aplicado na predição da produção de leite e, consequentemente, do nível ótimo de suplementação. No entanto, a avaliação da partição do quadrado médio do erro de predição do modelo indicou a necessidade de ajustamentos. A resposta produtiva marginal (RPMa) apresentou comportamento linear decrescente ao nível de CC: RPMa (kg leite/ kg de concentrado adicionado) = 1,5855 - 0,1104CC. O consumo de concentrado que maximiza o lucro por animal (CCótimo) é estimado pela seguinte equação: CCótimo (kg/vaca/dia, com base na matéria natural) = (1,5855 - (Px/Py))/0,1104; em que Px e Py são, respectivamente, os preços do concentrado (R $/ \mathrm{kg}$ de matéria natural) e do leite recebido pelo produtor $(\mathrm{R} \$ \mathrm{~kg})$. Sugere-se a realização de novos estudos para incorporar ao modelo indicadores de desempenho reprodutivo e outros fatores que afetam a resposta produtiva à suplementação com alimentos concentrados. Recomendações de níveis de suplementação com alimentos concentrados para bovinos devem basear-se nos pressupostos da teoria da análise marginal sob o risco de uso irracional dos nutrientes.
\end{abstract}

Palavras-chave: modelagem, otimização, produção de leite, resposta produtiva marginal 


\section{Introduction}

In the current feeding systems, recommendation of concentrate feeding for dairy cows follows protocols that aim to supply a specific nutritional demand not filled by the basal diet, according to an expected animal performance (Mertens, 1987; Fox et al., 1992; NRC, 2001).

However, in a logical way, recommendation for the best level of supplementation should consider, besides the animal response, the most economic efficiency of nutrient utilization and not only the supply of a specific nutritional demand. In spite of being logical, the adoption of this procedure in ruminant nutrition and production is still not a usual practice, although there are enough studies on production response to concentrate feeds (Davison \& Elliot, 1993; Gomide, 1993; Bargo et al., 2003; Lana, 2004; Lana et al., 2005a; Sairanen et al., 2006; Rennó et al. 2008). The absence of procedures for determining the optimal level of supplementation is the main reason for the low use of concentrates by dairy farmers.

The rationality of feed recommendation as a function of animal response is in accordance with the basic principles of the production economics, established at the end of the nineteenth century, which utilizes the marginal response analysis as an instrument for allocation of scarce resources in order to reach optimal results (Pinho, 1998).

The optimal amount of resources is determined by the relationship between the price of a production factor and the price of the product, in addition to the marginal physical productivity of the production factor, which corresponds to the increase in production resulting from addition of one unit of the production factor (Hoffmann et al., 1987), which is called marginal response analysis.

In order to apply the marginal response analysis as a criteria for recommendation of optimal level of supplementation, it is necessary to know the animal response to nutrient supply which can be obtained by the development of a prediction model. According to the principles of modeling and simulation, a model can be accepted and applied if it satisfies some basic criteria of model validation (Mertens, 1976).

The marginal production response of concentrate feeding in bovine under pastures condition is affected by several factors related to type of the concentrated, level of animal production and the quality of forage. The knowledge of these factors in low aggregation levels would make it possible to develop theoretical models that could support a better understanding of the phenomenon and it improves prediction animal response (Tedeschi et al., 2005). However, the shortage of such studies under tropical condition has made difficult, so far, the development of models with these characteristics.

In face of that situation, the use of empirical models, based on the direct relationship between concentrate intake and milk production comes as alternative due to the largest number of information reported in the literature. Thus, the objective of the present work is to apply a classic methodology for estimating the optimal level of concentrate feeds, based on the theory of marginal response, using an empiric predictive model of milk production response to increase the concentrate feeding level.

\section{Material and Methods}

In order to develop and to validate an empirical model, a database composed of 62 means of treatments was obtained from 31 studies on evaluation of milk production by cows on tropical pastures, with and without concentrate feeding (Aranovich et al, 1965; Lucci et al., 1969; Martinez et al., 1980; Vilela et al., 1980; Mozzer, 1987; Deresz \& Mozzer, 1990; Camargo Filho, 1991; Olivo et al., 1992; Alvim et al., 1993; Deresz, 1994; Alvim et al., 1995; Lascano, 1995; Camargo, 1996; Alvim et al., 1997; Coser et al., 1998; Fonseca et al., 1998; Alvim et al., 1999a; Alvim et al., 1999b; Soares et al., 1999; Leal et al., 2000; Deresz 2001; Gomes etal., 2002; Almeida etal., 2003; Fike et al., 2003; Gonçalves et al., 2003a; Gonçalves et al., 2003b; Carvalho et al., 2004; Neto et al., 2004; Wendling et al., 2004; Queiroz et al., 2005; Vilela et al., 2006).

Out of the total dataset, 43 means were obtained from crossbred Holstein $\times$ Zebu cows and 19 from Holstein purebred cows. The concentrates used in these studies presented approximately $19.3 \%$ crude protein content (standard error of 3\%), as fed basis.

The following genera of forage grasses with their respective number of observations (between parentheses) were evaluated: Pennisetum (21), Cynodon (13), Brachiaria (12), Panicum (6), Setaria (5), Digitaria (3), Melinis (1) and Paspalum (1).

The processes of construction and validation of the mathematical model followed the principles described by Mertens (1976). From all observations $60 \%$ were utilized in model development and $40 \%$ in model validation, randomly distributed. The predictive model of milk production response to concentrate intake was developed based on a function derived directly from the relationship between observed milk production and amount concentrate fed (empiric model). The adjustment was performed by the ordinary least square methods $(\alpha=0.05)$.

The function of production obtained and used for predicting milk production followed a polynomial regression model bellow: 


$$
\mathrm{Y}_{i}=\beta_{o}+\beta_{1} X_{i}+\beta_{2} X i^{2}+\ldots . .+\beta_{k} X i^{k}+e_{i}
$$

in which: $Y_{i}=$ milk production $(\mathrm{kg} / \mathrm{cow} /$ day) obtained at the $i$-th level of concentrate feeds ( $\mathrm{kg} / \mathrm{cow} /$ day); $\beta_{O}=$ intercept of the regression equation; $\beta_{k}=$ regression coefficient correspondent to linear, quadratic, ...., $k$-eth degree $(k=5)$; $\mathrm{X}_{\mathrm{i}}=i$-th level of the concentrate intake ( $\mathrm{kg} / \mathrm{cow} /$ day, as fed basis); $e_{i}=$ random error, assumed normally and independently distributed, with mean zero and variance $\sigma^{2}$. It was used SAEG (2007) for statistical analyses.

The models (1) was validated by fitting a linear regression equation on a series of predicted and observed values and assessing the regression parameters by $\mathrm{F}$ test, under the following simultaneous hypotheses testing according to Mayer et al. (1994):

Ho: $\beta_{0}=0$ and $\beta_{1}=1$ in which, $H o=$ null hypothesis; Bo $=$ intercept of linear regression between milk production (MP) observed and MP predict; and $\beta_{1}=$ slope. If $H o$ is not rejected, it can be concluded that the model predicts with similarity the observed values $(\alpha=0.05)$.

The efficiency of model prediction (1) was assessed by dividing the mean square prediction error (MSPE), according to the protocol described of Kobayashi \& Salam (2000), described below:

$$
\begin{aligned}
& \text { MSPE }=\text { SB }+ \text { SDSD + LCS } \\
& \text { SB }=(X-Y)^{2} \\
& \text { SDSD }=\left(s_{x}-s_{y}\right) \\
& \text { LCS }=2 s_{\mathrm{x}} S_{y}(1-r)
\end{aligned}
$$

in which: $\mathrm{SB}=$ squared bias; SDSD = squared difference between standard deviations; LCS = lack of correlation weighted by the standard deviations; $\mathrm{X}=$ mean of predicted values; $\mathrm{Y}=$ mean of observed values; $\mathrm{SDx}$ and $\mathrm{SDy}=$ standard deviation for the predicted and observed values, respectively; and $r$ = Pearson linear correlation between the predicted and observed values The prediction model is considered efficient if it presents low SB, SDSD and LCS (Kobayashi \& Salam, 2000).

The marginal production response of concentrate (MPR), defined as the rate of change in milk production due to increments of one unit of concentrate, was determined by the first derivative of equation (1), as described by Hoffmann et al. (1987):

$$
\mathrm{MPR}=d \mathrm{Y} / d \mathrm{X}
$$

in which: $\mathrm{MPR}=\mathrm{kg}$ of milk $/ \mathrm{kg}$ of concentrate fed; $=d \mathrm{Y} / d \mathrm{X}=$ rate of change in milk production ( $\mathrm{kg} / \mathrm{cow} /$ day) due to one unit increment in concentrate intake (kg/cow/day). Maximal milk production occurs when MPR is zero.

The optimal level of concentrate intake (CIoptimum), defined as the amount of concentrate that maximizes profit per animal, was determined based on the following condition, according to Hoffmann et al. (1987):

$\mathrm{MPR}=\mathrm{Px} / \mathrm{Py}$

in which: $\mathrm{Px}=$ concentrate price $(\$ / \mathrm{kg}) ; \mathrm{Py}=$ milk price $(\$ / \mathrm{kg})$.

\section{Results and Discussion}

By the amplitude of variation (minimum and maximum) the milk production (7.06 and $21.90 \mathrm{~kg} / \mathrm{day})$ and intake concentrate ( 0 and $8.20 \mathrm{~kg} /$ day) (Table 1 ), it can be assumed that the whole dataset obtained from the literature was representative of a wide range of conditions under which the Brazilian dairy production systems prevail.

Milk production on tropical pasture was only $10.554 \mathrm{~kg} /$ cow/day and a curvilinear response $(\mathrm{P}<0.05)$ was observed for milk production as a function of concentrate intake (Figure 1). If the model is accepted, a series of inferences on the efficiency of feed utilization can be done.

Table 1 - Descriptive statistics of the concentrate intake (CI, $\mathrm{kg} / \mathrm{cow} /$ day) and milk production (MP, kg/cow/day) dataset utilized in model development and model validation

\begin{tabular}{lcccccc}
\hline Statistic & \multicolumn{2}{c}{ Development } & & \multicolumn{2}{c}{ Evaluation } \\
\cline { 2 - 3 } & CI & MP & & CI $^{1}$ & MP \\
\hline Mean & 1.81 & 12.88 & & 2.20 & 13.29 \\
Minimum & 0.00 & 7.40 & & 0.00 & 7.06 \\
Maximum & 8.20 & 21.90 & & 6.70 & 20.80 \\
Standard deviation & 2.70 & 3.73 & & 2.69 & 3.94 \\
Number of observations & & 37 & & & 25 & \\
\hline
\end{tabular}

${ }^{1}$ As fed basis.

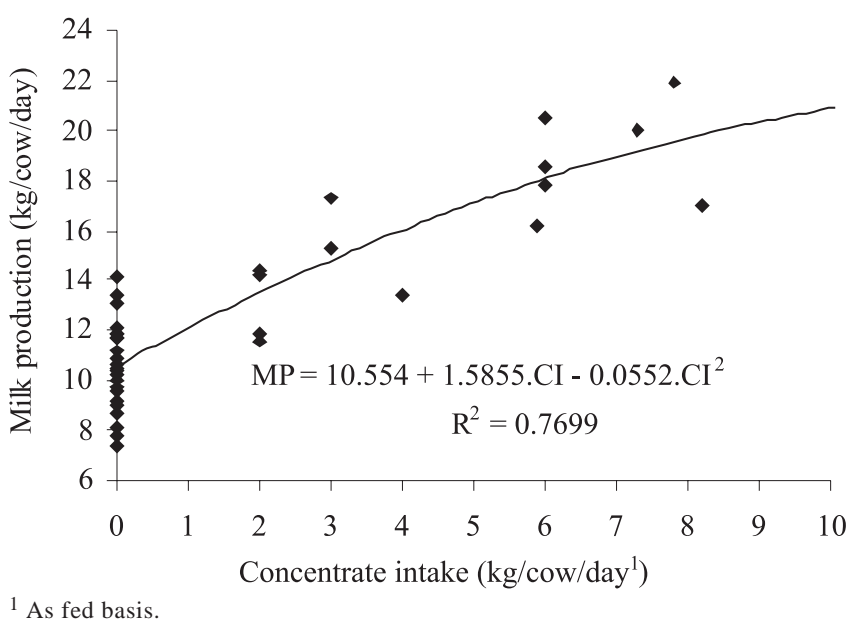

Figure 1 - Relationship between milk production (MP) and concentrate intake (CI) in dairy cows grazing tropical grass pasture. 
F-test for the regression equation of observed values over predicted values of milk production (Table 2 ) showed non-rejection of the null hypothesis ( $\mathrm{P}>0.05)$, indicating that the model (Figure 1) can be applied to predict milk production and to estimate marginal production and optimal concentrate feeding level.

The model for milk production predict with low constant bias $(0.13 \mathrm{~kg} /$ cow $/$ day = MP predicted - MP observed $)$, represents only $4.92 \%$ of the observed milk production value (Figure 2). The low effect of bias on the quality of prediction is due to the representative variables used and to the adopted model (empirical), which allows obtaining data that adjust well the single level of description or organization the hierarchy in biology (i.e., performance animal, crops yield) (Tedeschi et al., 2005; Thornley \& France, 2007).

The partition of MSPE indicates that although it gives low-bias estimates of milk production (small SB) and simulates the same magnitude (small SDSD), the model needs adjustments in the pattern of predictions of deviation from an observation based on the arithmetic mean of all observations of the evaluated dataset (large LCS) (Kobayashi \& Salam, 2000). This behavior can be better observed in Figure 3, where a wide dispersion of data above and bellow of the equality line $(\mathrm{Y}=\mathrm{X})$ is shown.

These adjustments can be obtained by including other factors that affect production responses of cows to concentrate feeding on tropical pastures, such as offer of potential digestible forage, type of concentrate feeds (energy $\times$ protein), sources of protein and carbohydrates in the concentrate, stage of lactation and period of utilization. Although trials have being carried out with beef cattle consuming tropical forages (Moraes et al., 2006; Paulino et al., 2006), there is a lack of studies with dairy cows under tropical conditions involving most of these factors. Thus, researches should be developed to better understand the pasture feeding system and the accuracy of animal performance predictions.

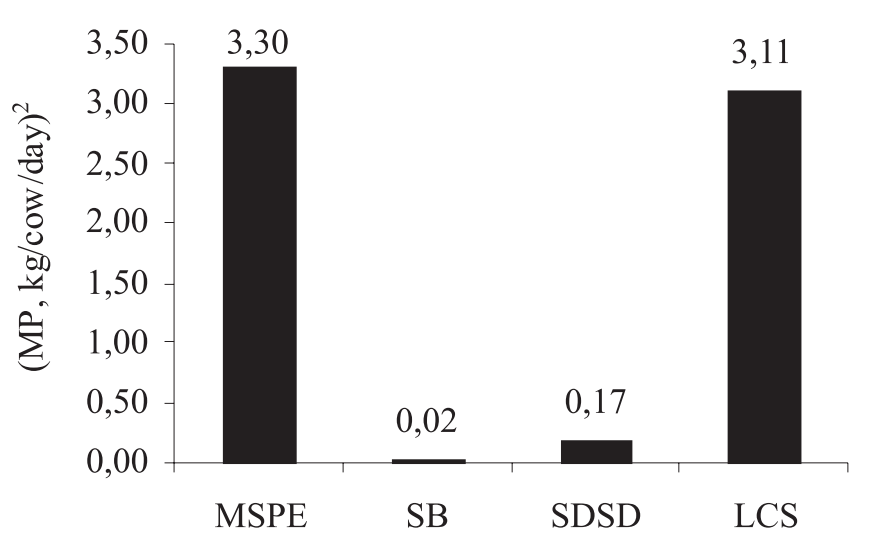

Figure 2 - Partition of mean square deviation (MSPE) for milk production (MP) in squared bias (SB), squared difference between standard deviations (SDSD) and lack of correlation weighted by the standard deviations (LCS) according to the regression equation $\mathrm{MP}=$ $10.554+1.5855 . \mathrm{CI}-0.0552 . \mathrm{CI}^{2}$.

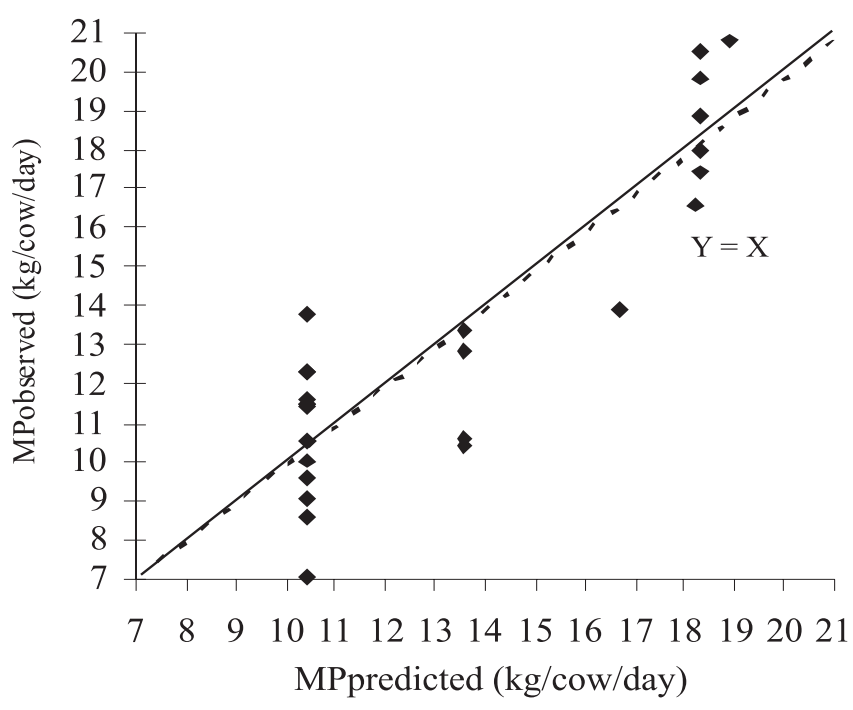

Figure 3 - Relationship between observed values of milk production (MP) and those predicted by the model showed in Figure 1. The dotted line corresponds to the line of minimum squares.

Table 2 - Means, estimates of regression parameters and statistics associated with the null hypothesis for the relationship between milk productions reported in the literature (observed values) and those predicted through the model $\mathrm{MP}=10.554+$ 1.5855.CI - 0.0552. $\mathrm{CI}^{2}$

\begin{tabular}{|c|c|c|c|c|c|}
\hline \multicolumn{2}{|c|}{ Item } & \multicolumn{3}{|c|}{ Linear regression } & \multirow[b]{2}{*}{ P-value ${ }^{1}$} \\
\hline Dependent variable (Y) & Independent variable (X) & Estimate & & & \\
\hline MPobserved (kg/cow/day) & MPpredited(kg/cow/day) & Intercept & Slope coefficient & $\mathrm{R}^{2}$ & \\
\hline 13.29 & 13.42 & 0.04128 & 0.9872 & 0.7802 & 0.9358 \\
\hline
\end{tabular}

${ }^{1 / H o:} \beta_{0}=0$ and $\beta_{1}=1$. 
The function of marginal production response can be obtained by the first derivative of the regression of milk production over concentrate feeding level (Figure 1), as it follows:

MPR $=1.5855-0.1104 \mathrm{CI}$

in which: $\mathrm{MPR}=$ marginal production response $(\mathrm{kg}$ of milk/kg of concentrate, as fed basis); CI = concentrate intake (kg/cow/day).

By considering a variation of CI from 1 to $10 \mathrm{~kg} /$ day, the MPR is estimated from 1.48 to $0.48 \mathrm{~kg}$ of milk/ $/ \mathrm{kg}$ of concentrate. So, the marginal production response is not constant, it decreases linearly as the amount of concentrate increases, showing a similar pattern to that described by Davison \& Elliott (1993) and Gomide (1993), who reported to have found, from a series of studies on response of milking cows to concentrate feeding on tropical pastures, a decrease in production response with the increase in supplementation level, a typical example of the law of diminishing returns.

The results differ from those of Bargo et al. (2003) and Lana (2004), in which, by evaluating data from a series of experiments with milking cows grazing temperate and tropical pastures, respectively, totalizing 35 and 22 means of treatments, it was found constant values for production response of $1.0 \mathrm{~kg}$ of milk/ $\mathrm{kg}$ of dry matter of concentrate and $0.65 \mathrm{~kg}$ of milk/kg of concentrate as fed, respectively. Their results indicate linear responses of milk production to increase in concentrate intake, which are not in agreement with the curvilinear biological responses to nutrient supply, as reported by Russell (1984) and Lana et al. (2005a). In addition, the equations proposed by Bargo et al. (2003) and Lana (2004), and those described by Davison \& Elliott (1993) were not evaluated with independent database, restraining their adoption and application (Mertens, 1976).

Furthermore, the values of feed utilization efficiency found by Davison \& Elliott (1993), Gomide(1993), Bargo et al. (2003) and Lana (2004) were calculated in relation to control treatments (production responses) and not in relation to the previous level of supplementation (marginal production responses), which overpredicted the response to supplementation, and did not allow to find the optimal level (Hoffman et al., 1987). The overprediction of efficiency by using the production response approach is due to the additive effect of greater efficiencies of the lowest levels on the actual level, which does not occur when the marginal production response approach is utilized.

Despite of an average theoretical production response of $2.3 \mathrm{~kg}$ of milk/kg of concentrate reported in the literature (Gomide, 1993; NRC 2001; Lana et al., 2005b), values of MPR bellow $1.58 \mathrm{~kg}$ of milk/kg of concentrate and a decreasing marginal response were found in the present work. At least two theories can justify the observation of decreasing MPR to supplementation.

The first theory assumes that the production response is a reflex of substitution rate, which corresponds to the decrease in pasture intake by increasing concentrate intake (Cowan et al., 1977; Vilela et al., 1980; Davison \& Elliott, 1993; Gomide, 1993; Bargo et al., 2003). Accordingly, the increase in concentrate intake increases the substitution rate and, then, decreases the production response to supplementation. The decrease in pasture intake with increase in concentrate level is related to the reduction in digestibility of neutral detergent fiber due to low $\mathrm{pH}$ and ruminal $\mathrm{N}-\mathrm{NH}_{3}$ concentration, with reduction in time spent on grazing and with physiological satiety (Paterson et al., 1994; Bargo et al., 2003).

The second theory considers that the production response to concentrate feeding follows the same curvilinear response of enzymatic system to the substrate supply (Lana et al., 2005a). Considering enzymes as fundamental units of cellular metabolism, it can be inferred that with the increase of nutrient supply, decreasing positive response occurs up to the limit in which the response becomes negative due to the inhibition caused by toxicity. This is a kind of physiological response that occurs in all biological systems, such as microorganisms (Russell, 1984), plants and animals (Lana et al., 2005a). Under this condition, the replacement of pasture by concentrates is the effect and not the cause of reduction in production response.

By replacing (7) in (8), the optimal level of concentrate intake is described as:

$$
\begin{aligned}
& 1.5855-0.1104 \mathrm{CI}=\mathrm{Px} / \mathrm{Py} \\
& \text { CIoptimum }=((1.5855-(\mathrm{Px} / \mathrm{Py})) / 0.1104
\end{aligned}
$$

in which : CIoptimum = optimum level intake of concentrate that maximizes profit per cow (kg/cow/day); $\mathrm{Px}=$ concentrate price ( $\$ / \mathrm{kg}$ of concentrate as fed basis); Py = milk price at farmgate $(\$ / \mathrm{kg})$. Considering a variation in the quotient (Px/Py) from 1.50 to 0.50 , CIoptimum ranges from 0.77 to $9.83 \mathrm{~kg} /$ cow/day. It is not economically feasible when

Table 3 - Optimal level concentrate intake (CIoptium), in kg/ cow/day, for lactating cows on tropical pastures, as a function of different prices of concentrate (Px) and of

\begin{tabular}{|c|c|c|c|c|c|}
\hline \multirow{2}{*}{$\begin{array}{l}\text { Milk price } \\
\text { Py }(\$ / k g)\end{array}$} & \multicolumn{5}{|c|}{ Concentrate price $(\$ / \mathrm{kg})$ Px } \\
\hline & 0.30 & 0.40 & 0.50 & 0.60 & 0.70 \\
\hline 0.35 & 6.60 & 4.01 & 1.42 & 0.00 & 0.00 \\
\hline 0.40 & 7.57 & 5.30 & 3.04 & 0.77 & 0.00 \\
\hline 0.50 & 8.93 & 7.12 & 5.30 & 3.49 & 1.68 \\
\hline 0.55 & 9.42 & 7.77 & 6.13 & 4.48 & 2.83 \\
\hline
\end{tabular}
milk (Py), estimated through equation (9b) 
concentrate price is 1.5855 times superior to milk price supplementation. In this way, the optimal amount of concentrate depends on the price ratio concentrate and milk, which has a wide variation of effects (Table 3).

Figure 4 shows results of a simulation when concentrate price (Px) of \$ 0.52/kg and milk price (Py) of \$ 0.50/kg were considered, making Px/Py equal to 1.03. The milk production value was calculated by multiplying the milk price by the milk production estimated through the model (Figure 1). The cost of supplementation was calculated by multiplying the price of concentrate by its intake. The margin overconcentrate cost (MOCC) represents the difference between the production value and the cost of supplementation.

By utilizing these values in equation (9b), it can observed that MOCC is maximized at concentrate feeding level equal to $5 \mathrm{~kg} / \mathrm{cow}$, exactly at the point on marginal production response is equal to $1.03 \mathrm{~kg}$ of milk/kg of concentrate.

In a review paper on milk production under grazing condition, Gomide (1993) concluded that due to low production response to supplementation on pasture, the supplementation is only economically justified when the price of milk/price of concentrate ratio is equal to 2 or 3 . However, definitions about optimal level of supplementation as presented in this work were not mentioned.

The optimal level of supplementation explains the pattern of concentrate utilization over the year by dairy farmers who adjust the amount to be given to the milking cows according to the variation in price ratio between milk and concentrate(Px/Py)(SEBRAE-MG, 1996; FAEMG, 2006). Periods when the price ratio ( $\mathrm{Px} / \mathrm{Py}$ ) increases as a function of increase in concentrate price and/or decrease in milk price, requires increase in MPR to compensate the loss of purchasing power and to maintain profit per animal. This compensation is made by reducing the concentrate supply until MPR becomes equal to the quotient $\mathrm{Px} / \mathrm{Py}$, since as previously stated, MPR is great by lowering the price of concentrate. Conversely, reduction in the price ratio as a function of decrease in concentrate price and/or increase in milk price, requires reduction in MPR to maximize profit per animal. This reduction in MPR is made by increasing concentrate supply.

Based on the assumptions of production theory (Hoffmann et al., 1987), below the optimal point (i.e. $5 \mathrm{~kg} /$ cow/day, in Figure 4) stage I of production is found where increase in concentrate intake increases profit per cow up to the maximum which can be found in the transition between productive stages I and II. Above the optimum point, it begins the stage II of production, characterized by the decrease in profit with an increase in concentrate intake until the point in which the profit becomes equal to the level zero supplementation (i.e. $10 \mathrm{~kg} / \mathrm{cow} /$ day, in Figure 4). After that point, stage III of production starts, where the profit per animal becomes inferior to the level zero of concentrate supplementation and the decrease keeps with increase in concentrate intake. Accordingly, only on the transition between the stages I and II (optimal point), the concentrate is utilized in a rational way. This optimal point represents concentrate intake in which MPR is equal to price ratio between milk and concentrate (Px/Py).

Models of production response to supplementation with concentrates should consider all physiological functions of a specific animal category. In addition to milk production, the level of supplementation affects reproductive performance. Thus, the most adequate responsive variable is milk production per day of calving interval, since it comprises both performance parameters for production and reproduction. However, studies on these parameters are scarce under tropical pasture conditions, making it difficult to include reproductive variable in the prediction model. Then, it is suggested to develop more research on this issue in order to improve the quality of predictions of production and economic responses to concentrate feeding in dairy cows.

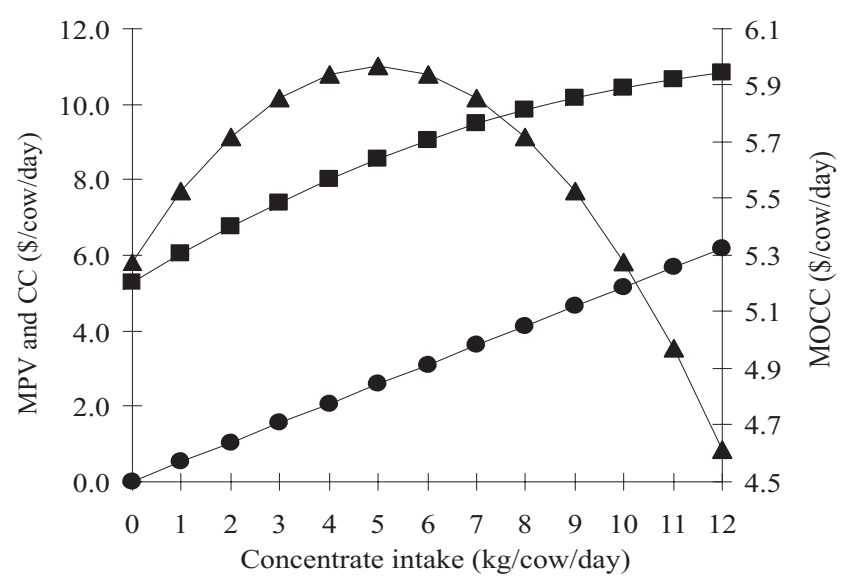

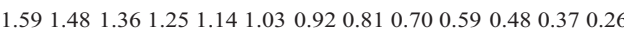

$\operatorname{MPR}(\mathrm{kg}$ milk/ $\mathrm{kg}$ of concentrate)

Figure 4 - Simulation of milk production value (MPV) ( $\square$ ), concentrate cost (CC) $(\bullet)$ and margin over concentrate cost (MOCC) ( $\mathbf{\Delta}$ ) as a function of concentrate intake and respective value of marginal productive response (MPR). 


\section{Conclusions}

The curvilinear production function obtained from a series of response data taken from literature and its first derivative, as marginal production response, showed to be adequate for estimating the levels of supplementation that maximize margin over concentrate cost at different input/output price ratios. However, in order to improve the model predictive ability, more field experimentation is needed to allow the inclusion of reproduction milk components as response variable as well as other factors that affect production response to supplementation in a pasture-based system for dairy cows. Recommendations concerning levels of concentrate feeding for bovines should apply the theory of marginal analysis to avoid irrational use of nutrients. Therefore, the marginal production response and the input/output price ratio are the key variables that define the optimal level of concentrate supplementation for dairy cows.

\section{References}

ALMEIDA, E.X.; SETELICH, E.A. Potential milk production on dwarf elephantgrass (pennisetum purpureum schum. cv. mott) pasture in Alto Vale do Itajaí, Santa Catarina. In: REUNIÃO ANUAL DA SOCIEDADE BRASILEIRA DE ZOOTECNIA, 40., 2003, Santa Maria. Anais... Rio Grande do Sul: Sociedade Brasileira de Zootecnia, 2003. (CD-ROM).

ALVIM, M.J.; BOTREL, M.A.; MARTINS, C.E. et al. Produção de leite em pastagens de capim-angola e de setária. Coronel Pacheco: Embrapa-CNPGL, 1995. 30p. (Circular Técnica, 37).

ALVIM, M.J.; VERNEQUE, R.S.; VILELA, D. et al. Effects of two levels of concentrate on milk production of Holstein cows grazing a coast-cross. Brazilian Journal of Agricultural Research, v.34, n.9, p.1711-1720, 1999a.

ALVIM, M.J.; BOTREL, M.A.; MARTINS, C.E. et al. Milk production of holstein cows in coast-cross-1 pasture, fertilized with three levels of nitrogen. In: REUNIÃO ANUAL DA SOCIEDADE BRASILEIRA DE ZOOTECNIA, 36., 1999, Porto Alegre. Anais... Porto Alegre: Sociedade Brasileira de Zootecnia, 1999b. (CD-ROM).

ALVIM, M.J.; MARTINS, C.E.; BOTREL, M.A. et al. Effect of herbage availability on milk production of crossbred cows grazing setaria pasture (Setaria sphacelata, cv. kazungula). Revista Brasileira de Zootecnia, v.22, n.3, p.380-388, 1993.

ALVIM, M.J.; VILELA, D.; LOPES, R.S. Effects of two levels of concentrate on milk production of Holstein cows Grazing a coast-cross (Cynodon dactylon (1.) Pers) Pasture. Revista Brasileira de Zootecnia, v.26, n.5, p.967-975, 1997.

ARONOVICH, S.; CORREIA, A.N.S.; FARIA, E.V. O uso de concentrado na alimentação de vacas leiteiras em boas pastagens de capim-pangola. 1 - resultados de verão. CONGRESSO INTERNACIONAL DE PASTAGENS, 9., 1965, São Paulo. Anais... São Paulo, 1965. p.919-921.

BALIEIRO NETO, G. FERREIRA, J.J.; FREIRE, F.M. et al. Productility of tifton-85 (Cynodon spp) and viability of the system of production of milk in pasture on irrigated. In: REUNIÃO ANUAL DA SOCIEDADE BRASILEIRA DE ZOOTECNIA, 41., 2004, Campo Grande. Anais... Campo Grande: Sociedade Brasileira de Zootecnia, 2004. (CD-ROM).
BARGO, F.; MULLER, L.D.; KOLVER, E.S. Invited review: Production and digestion of supplemented dairy cows on pasture. Journal of Dairy Science, v.86, n.1, p.1-42, 2003.

CAMARGO, A.C. Produção de leite a pasto. In: PEIXOTO, A.M.; MOURA, J.C.; FARIA, V.P. (Eds.). Produção de bovinos a pasto. In: SIMPÓSIO SOBRE MANEJO DE PASTAGENS, 13. 1996, Piracicaba. Anais... São Paulo: FEALQ, 1996. p.221-242.

CAMARGO FILHO, S.T. Produção de leite de vacas mestiças em pastagens de Brachiaria decumbens com uso suplementar de ração concentrada ou adubação. In: REUNIÃO ANUAL DA SOCIEDADE BRASILEIRA DE ZOOTECNIA, 28., 1991, João Pessoa. Anais... João Pessoa: Sociedade Brasileira de Zootecnia, 1996, p.140.

CARVALHO, C.A.B.; DERESZ, F.; PACIULLOM, D.S.C. et al. Milk production and carry capacity of the napier grass pastures managed in two grazing intervals and two stubble heigths. In: REUNIÃO ANUAL DA SOCIEDADE BRASILEIRA DE ZootecniA, 41., 2004, Campo Grande. Anais... Campo Grande: Sociedade Brasileira de Zootecnia, 2004. (CD-ROM).

CÓSER, A.C.; DERESZ, F.; MARTINS, C.E. Período de utilização de capim-elefante em pastagens. In: Pastejo de capim elefante. Informe Agropecuário, v.19, n.192, p.33-35, 1998.

COWAN, R.T.; DAVISON, T.M.; O'GRADY, P. Influence of level of concentrate feeding on milk production and pasture utilization by friesian cows grazing tropical grass-legume pasture. Australian Journal Experimental Agriculture Animal Husbandry, v.17, n.86, p.373-379, 1977.

DAVISON, T.M.; ELLIOTT, R. Response of lactating cows to grainbased concentrates in northern Australia. Tropical Grasslands, v.27, p.229-237, 1993.

DERESZ, F.; MOZZER, O.L. Produção de leite em pastagem de capim elefante. In: SIMPÓSIO SOBRE CAPIM ELEFANTE, 1., 1990, Juiz de Fora. Anais... Coronel Pacheco: EmbrapaCNPGL, 1990. p.155-172.

DERESZ, F. Manejo de pastagem de capim-elafente para produção de leite e carne. In: SIMPÓSIO SOBRE CAPIM ELEFANTE, 2., 1994, Juiz de Fora. Anais... Coronel Pacheco: EmbrapaCNPGL, 1994. p.116-137.

DERESZ, F. Milk yield of crossbred holstein x zebu cows grazing elephant grass pasture rotationally managed supplemented or not with concentrate. Revista Brasileira de Zootecnia, v.30, n.1, p.197-204, 2001.

FEDERAÇÃO DA AGRICULTURA DO ESTADO DE MINAS GERAIS FAEMG. Diagnóstico da pecuária leiteira do estado de Minas Gerais em 2005. Relatório de pesquisa. Belo Horizonte, 2006. 156p.

FIKE, J.H.; STAPLES, C.R.; SOLLENBERGER, L.E. Pasture Forages, supplementation rate, and stocking rate effects on dairy cow performance. Journal of Dairy Science, v.86, p.1268-1281, 2003.

FONSECA, D.; SALGADO, T.L.; QUEIROZ, D.S. et al. Produção de leite em pastagem de capim-elefante sob diferentes períodos de ocupação dos piquetes. Revista Brasileira de Zootecnia, v.27, n.5, p.848-856, 1998.

FOX, D.G.; SNIFFEN, C.J.; O'CONNOR, J.D. et al. A net carbohydrate and protein system for evaluating cattle diets: III. Cattle requirements and diet adequacy. Journal of Animal Science, v.70, n.12, p.3578-3596, 1992.

GOMES, I.P.O.; THALER NETO, A.; SEMMENLMANN, C.E.N. et al. Production responses of dairy cows grazing kikuyu grass (Pennisetum clandestinum) pastures to energy and protein supplementation. In: REUNIÃO ANUAL DA SOCIEDADE BRASILEIRA DE ZOOTECNIA, 39., 2002, Recife. Anais... Pernambuco: Sociedade Brasileira de Zootecnia, 2002. (CD-ROM).

GOMIDE, J.A. Milk production under grazing. Revista Brasileira de Zootecnia, v.22, n.4, p.591-613, 1993.

GONÇALVES, C.A.; CAMARÃO A.P.; RODRIGUES FILHO, J.A. et al. Milk production in pasture of Panicum maximum cv. Tobiatã with and without supplementation of concentrate. In: 
REUNIÃO ANUAL DA SOCIEDADE BRASILEIRA DE ZOOTECNIA, 40., 2003, Santa Maria. Anais... Santa Maria: Sociedade Brasileira de Zootecnia, 2003a. (CD-ROM).

GONÇALVES, C.A.; CAMARÃO A.P.; DUTRA, S. et al. Milk production in intensive rotational grazing on "brachiaria brizantha" cv. Marandu under two levels of concentrate supplementation. In: REUNIÃO ANUAL DA SOCIEDADE BRASILEIRA DE ZOOTECNIA, 40., 2003, Santa Maria. Anais... Santa Maria: Sociedade Brasileira de Zootecnia, 2003b. (CD-ROM).

HOFFMANN, R.; SERRANO, O.; NEVES, E.M. et al. Administração da empresa agrícola. 5.ed. São Paulo: Pioneira, 1987. 325p.

KOBAYASHI, K.; SALAM, M.U. Comparing simulated and measured values using mean squared deviation and its components. Agronomy Journal, v.92, n.2, p.345-352, 2000.

LANA, R.P. Efficiency of use of concentrate ration on weigth gain and milk production by cattle under tropical and intensive condition in Brazil. Journal of Animal Science, v.82, Suppl.1, p.222, 2004.

LANA, R.P.; GOES, R.H.T.B.; MOREIRA, L.M. et al. Application of lineweaver-Burk data transformation to explain animal and plant performance as a function of nutrient supply. Livestock Production Science, v.98, n.3, p.219-224, 2005a.

LANA, R.P.; GOES, R.H.T.B.; MOREIRA, L.M. et al. Nova sistemática de avaliação de respostas produtivas (crescimento animal, vegetal, microbiano e produção de leite) ao suprimento variável de nutrientes. In: LANA, R.P. (Ed.) Nutrição e alimentação animal (mitos e realidades). Viçosa, MG: Editora UFV, 2005b. p.265-292.

LASCANO, C.E. Componentes forrajeros de comportaminento reconocido em sistemas de producción. Informe Bianul 1994-1995. CIAT - Programa de Forrajes Tropicalles, 1995, p.8-13 (Documento de Trabajo, 153).

LEAL, J.A.; BONA NASCIMENTO, M.P.S.C. Produção de leite em pastagem irrigada. In: SIMPÓSIO DE FORRAGICULTURA E PASTAGENS, 1., 2000, Lavras. Anais... Lavras: UFLA, 2000. p.311-356.

LUCCI, C.S.; ROCHA, G.L.; KALIL, E.B. Produção de leite em pastagens de capim -fino e capim-napier. Boletim da Indústria Animal, v.26, p.173-180, 1969.

MARTINEZ, R.O.; RUIZ, R.; HERREIRA, R. Milk production of cows grazing coast-cross $n^{\circ} 1$ bermudagrass (Cynodon dactylon). 1. Different concentrate supplementation levels. Cuba Journal Agriculture Science, v.14, n.2, p.225-232, 1980.

MAYER, D.G.; STUART, M.A.; SWAIN, A.J. Regression of realworld data model output: an appropriate overall test of validity. Agriculture Systems, v.45, p.93-104, 1994.

MERTENS, D.R. Principles of modeling and simulation in teaching and research. Journal of Dairy Science, v.60, n.7, p.1176-1186, 1976.

MERTENS, D.R. Predicting intake and digestibility using mathematical models of ruminal function. Journal of Animal Science, v.64, p.1548-1558, 1987.

MORAES, K.A.K.; MORAES, E.H.B.; DETMANN, E. et al. Factors that influence the performance of beef cattle at pasture during dry season. In: REUNIÃO ANUAL DA SOCIEDADE BRASILEIRA DE ZOOTECNIA, 43., 2006, João Pessoa. Anais... João Pessoa: Sociedade Brasileira de Zootecnia, 2006. (CD-ROM).

MOZZER, O.L. Produção de leite em pastagem de capim-elefante. In: REUNION SOBRE PRODUCCIÓN DE PASTURAS PARA ENGORDE Y PRODUCCIÓN DE LECHE, La Estanzuela. Motevídeo, 1987. Anais... Motevídeo: IICA/BID/PROCISUR, 1987. p.231-235. (PROCISUR. Diálogo XIX).

NATIONAL RESEARCH COUNCIL - NRC. Nutrient requirements of dairy cattle. 7.ed. Washington, D.C.: National Academy of Sciences, 2001. 381p.
OLIVO, C.J.; MOREIRA, J.C.; BARRETO, I.L. et al. Comparison of elephant and setaria grass with grazing dairy cows during Summer. Revista Brasileira de Zootecnia, v.21, n.3, p.347-358, 1992.

PATERSON, J.A.; BELYEA, R.L.; BOWMAN, J.P. et al. The impact of forage quality and supplementation regimen on ruminant animal intake and performance. In: FAHEY JR., G.C.; COLLINS, M; MERTENS, D.R. et al. (Eds.) Forage quality, evaluation and utilization. Madison, 1994. p.59-114.

PAULINO, M.; DETMANN, E.; VALADARES FILHO, S.C. Suplementação animal em pasto: energética ou protéica?. In: SIMPÓSIO SOBRE MANEJO ESTRATÉGICO DE PASTAGEM, 3., 2006, Viçosa, MG. Anais... Viçosa, MG, 2006. p.359-392.

PINHO, D.B. Evolução da ciência econômica. In: PINHO, D.B; VASCONCELLOS, M.A.S. (eds.) Manual de economia. 3.ed. São Paulo: Saraiva, 1998. p.31-66.

QUEIROZ, D.S.; SALGADO, T.S.; MOURA, G.S. et al. Forage grass evaluation under continuous stocking in lowland soil: ii. chemical composition and milk production. In: REUNIÃO ANUAL DA SOCIEDADE BRASILEIRA DE ZOOTECNIA, 42., 2005, Goiânia. Anais... Goiânia: Sociedade Brasileira de Zootecnia, 2005. (CD-ROM).

RENNÓ, F.P.; PEREIRA, J.C. ; LEITE, C.A.M et al. Bioeconomic efficiency of cows of different milk yield levels per lactation and feeding strategies. Revista Brasileira de Zootecnia, v.37, n.4, p.765-772, 2008.

RUSSELL, J.B. Factors influencing competition and composition of the ruminal bacterial flora. In: GILCHRIST, F.M.C.; MACKIE, R.I. (Eds.) The herbivore nutrition in the subtropics and tropics. Craighall, South Africa: Science Press, 1984, p.313-345.

UNIVERSIDADE FEDERAL DE VICOSA - UFV. SAEG - Sistema para análises estatísticas. versão 9.1: Fundação Arthur Bernardes - UFV - Viçosa, 2007. (CD-ROM).

SAIRANEN, A.; KHALILI, H.; VIRKAJÄRVI, P. Concentrate supplementation responses of the pasture-fed dairy cow. Livestock Production Science, v.104, n.3, p.292-302, 2006.

SEBRAE-MG. DIAGNÓSTICO DA PECUÁRIA LEITEIRA DO ESTADO DE MINAS GERAIS Relatório de pesquisa: Tabelas. FAEMG - Belo Horizonte, 1996, 212p.

SOARES, J.P.G.; AROEIRA, L.J.M.; PEREIRA, O.G. et al. Elephant grass (Pennisetum purpureum Schum.) fertilized with two levels of nitrogen, under grazing, voluntary intake and milk production. Revista Brasileira de Zootecnia, v.28, n.4, p.889-897, 1999.

TEDESCHI, L.O.; FOX, D.G.; SAINZ, R.D. et al. Mathematical models in ruminant nutrition. Scientia Agricola, v.62, n.1, p.76-91, 2005

THORNLEY, J.H.M.; FRANCE, J. Mathematical models in agriculture: quantitative methods for the plant, animal and ecological science. 2.ed. Wallingford: CABI International, 2007. 906p.

VILELA, D.; CARDOSO, R.M.; SILVA, J.F.C. et al. Efeito da suplementação concentrada sobre o consume de nutrientes e a produção de leite de vacas em pastagem de capim-gordura. Revista da Sociedade Brasileira de Zootecnia, v.9, n.2, p.214-233, 1980.

VILELA, D.; LIMA, J.A.; RESENDE, J.C. et al. Performance of holsteins cows on coast-cross pasture suplemented with concentrate. In: REUNIÃO ANUAL DA SOCIEDADE BRASILEIRA DE ZOOTECNIA, 42., 2005, Goiânia. Anais... Goiás: Sociedade Brasileira de Zootecnia, 2005. (CD-ROM).

WENDLING, I.J.; ALENCAR, C.A.B.; TEIXEIRA, S.R. et al. Milk production of crossbread hostein x zebu cows, in elephant grass grass grazing at two rest periods. In: REUNIÃO ANUAL DA SOCIEDADE BRASILEIRA DE ZOOTECNIA, 41., 2004, Campo Grande. Anais... Mato Grosso do Sul: Sociedade Brasileira de Zootecnia, 2004. (CD-ROM). 